\title{
Host Resistance to Mirafiori lettuce big-vein virus and Lettuce big-vein associated virus and Virus Sequence Diversity and Frequency in California
}

\author{
Ryan J. Hayes, William M. Wintermantel, Patricia A. Nicely, and Edward J. Ryder, United States Department of \\ Agriculture, Agricultural Research Service, Crop Improvement and Protection Unit, 1636 E. Alisal St., Salinas, CA \\ 93905
}

\begin{abstract}
Hayes, R. J., Wintermantel, W. M., Nicely, P. A., and Ryder, E. J. 2006. Host resistance to Mirafiori lettuce big-vein virus and Lettuce big-vein associated virus and virus sequence diversity and frequency in California. Plant Dis. 90:233-239.

Big vein is an economically damaging disease of lettuce (Lactuca sativa) caused by the $\mathrm{Ol}$ pidium brassicae-vectored Mirafiori lettuce big-vein virus (MLBVV). Lettuce big-vein associated virus (LBVaV) is also frequently identified in symptomatic plants, but no causal relationship has been demonstrated. Although big vein is a perennial problem in the United States, the extent of MLBVV and LBVaV infection and diversity is unknown. Lettuce cultivars partially resistant to big vein reduce losses, but do not eliminate disease. While Lactuca virosa does not develop big vein symptoms, it has not been tested for infection with MLBVV or LBVaV. Lettuce cultivars Great Lakes 65, Pavane, Margarita, and L. virosa accession IVT280 were evaluated for big vein incidence and virus infection in inoculated greenhouse trials. Additional lettuce samples were collected from field sites in California, classified for symptom severity, and evaluated for virus infection. Reverse transcription-polymerase chain reaction and nucleotide sequencing were used to determine infection with MLBVV and LBVaV, and sequence diversity among viral isolates, respectively. Infections with MLBVV and MLBVV/LBVaV were dependent on big vein symptom expression in California production areas, and isolates were closely related to those found in Europe and Japan. Partial big vein resistance was identified in Margarita and Pavane; however, MLBVV infection was found in asymptomatic plants. L. virosa IVT280 remained symptomless and virus free, suggesting that it is immune to MLBVV and LBVaV.
\end{abstract}

Big vein is a viral disease of lettuce (Lactuca sativa L.) transmitted by the soilborne fungus Olpidium brassicae (7). Symptoms of big vein include chlorosis surrounding the vascular bundles in the leaf and increased stiffness of the leaves. In iceberg lettuce, this can disrupt normal head development, resulting in plants that have a bushy appearance. The primary source of economic damage resulting from big vein disease is a reduction in the number of heads formed. Big vein is most prevalent in cool wet soils $(4,22,23)$, and increases with continuous lettuce production without rotation. Consequently, big vein consistently occurs at high levels during spring production in California's coastal growing districts, and during winter production in Arizona.

Effective long-term control of big vein disease is best accomplished through genetic resistance and is important for sustainable production of quality lettuce in

Corresponding author: Ryan J. Hayes

E-mail: rhayes@pw.ars.usda.gov

Accepted for publication 29 September 2005.

DOI: 10.1094/PD-90-0233

This article is in the public domain and not copyrightable. It may be freely reprinted with customary crediting of the source. The American Phytopathological Society, 2006
California and Arizona, where $99 \%$ of U.S. lettuce production occurs (1). Complete resistance to big vein has only been identified in accessions of Lactuca virosa L. (2), but this resistance has not been introgressed into lettuce cultivars. Among cultivated lettuce, cultivars are available with partial resistance that can be measured by reduced frequency of symptomatic plants or symptom expression that is delayed until plants reach market maturity (15). This type of resistance has greatly improved marketable yields in fields infested with big vein (14). Progress in increasing the level of partial resistance has been slow, primarily because of a lack of information regarding the pathogen, the unknown inheritance of resistance, and the large influence that environmental conditions have on symptom expression.

Although big vein disease has affected lettuce production for many years, the causal agent, Mirafiori lettuce big-vein virus (MLBVV) (genus Ophiovirus), formerly known as Mirafiori lettuce virus, was only recently identified $(8,11)$. Another virus, Lettuce big-vein associated virus (LBVaV) (genus Varicosavirus), formerly known as Lettuce big-vein virus, was previously found associated with big vein disease, but a causative relationship was never confirmed $(6,21)$. Interestingly, many studies have demonstrated that plants exhibiting big vein symptoms were frequently coinfected with both viruses, suggesting $\mathrm{LBVaV}$ may also contribute in some manner to the disease $(9,10,12)$.

LBVaV and MLBVV both encode most of their proteins on the negative or complementary sense RNA $(16,20)$. The genome of $\mathrm{LBVaV}$ is bipartite. RNA1 encodes an RNA-dependent RNA polymerase (16), while RNA2 encodes five additional open reading frames, including the viral coat protein (CP) (17). The genome of MLBVV contains four separate RNAs. The $48.5 \mathrm{kDa} \mathrm{CP}$ is encoded on RNA3 (20). By comparing viral CP nucleotide sequences, Navarro et al. (10) demonstrated that $\mathrm{LBVaV}$ isolates from lettuce in Europe were closely related to each other, and to several isolates from around the world. European MLBVV isolates were also found to be highly conserved; however, these isolates could be separated into two subgroups.

Understanding the distribution of MLBVV and LBVaV in California and the genetic relationships among virus isolates in this region is important for the development of control methods suitable for production conditions in the western United States. Additionally, knowledge of the virus or viruses responsible for big vein disease may facilitate development of more effective resistance screening methods and identification of plants not only with reduced symptom expression, but also with reduced virus infection. The objectives of this research were to determine (i) the frequency of MLBVV and LBVaV infection in California field-grown lettuce, (ii) the frequency of MLBVV and LBVaV infection in greenhouse-inoculated $L$. $s a$ tiva cultivars and $L$. virosa breeding material, and (iii) the sequence diversity of MLBVV and LBVaV isolates from California.

\section{MATERIALS AND METHODS}

Collection of field samples and classification of symptom severity. Lettuce leaf samples were collected for virus RNA isolation from field sites in the California central-coast production area. Commercial lettuce fields (cultivars unknown) were arbitrarily chosen for sampling from diverse sites within a $3,600 \mathrm{~km}^{2}$ region covering three lettuce-growing districts. Seven locations were sampled throughout the Salinas Valley, including two near Salinas, 
and from sites near Chualar, Gonzales, Soledad, Greenfield, and King City. Individual locations were also sampled near San Juan Bautista in the Santa Clara Valley and Watsonville in the Pajaro Valley. One field was chosen per location, and five to nine plants per field were sampled by collecting one complete leaf per plant. Leaves were stored on ice, brought into the lab, and classified as healthy, mild, moderate, or severe for big vein symptoms using the disease severity scale illustrated in Figure
1. Lettuce tissue was sampled (100 mg per sample), lyophilized, and stored at $-80^{\circ} \mathrm{C}$ prior to RNA extraction.

Greenhouse testing of big vein resistance. Three sets of greenhouse experiments were performed to compare big vein resistance among $L$. sativa cultivars and $L$. virosa. Experiment 1 used three separate inoculations of the cultivars Great Lakes 65, Pavane, and Margarita with three replications of 12 plants. Great Lakes 65 and Pavane were previously reported to be susceptible and partially resistant, respectively (15). Experiment 2 used Great Lakes 65, Pavane, and L. virosa accession IVT280 in five inoculations of one to three replications of 12 plants. Experiment 3 was not replicated and involved up to 14 plants per genotype of Great Lakes 65, Margarita, and L. virosa IVT280 in a single inoculation. Each inoculation was conducted by following the protocol of Ryder and Robinson (15). Seedlings were germinated in a potting mix containing a $2: 1$

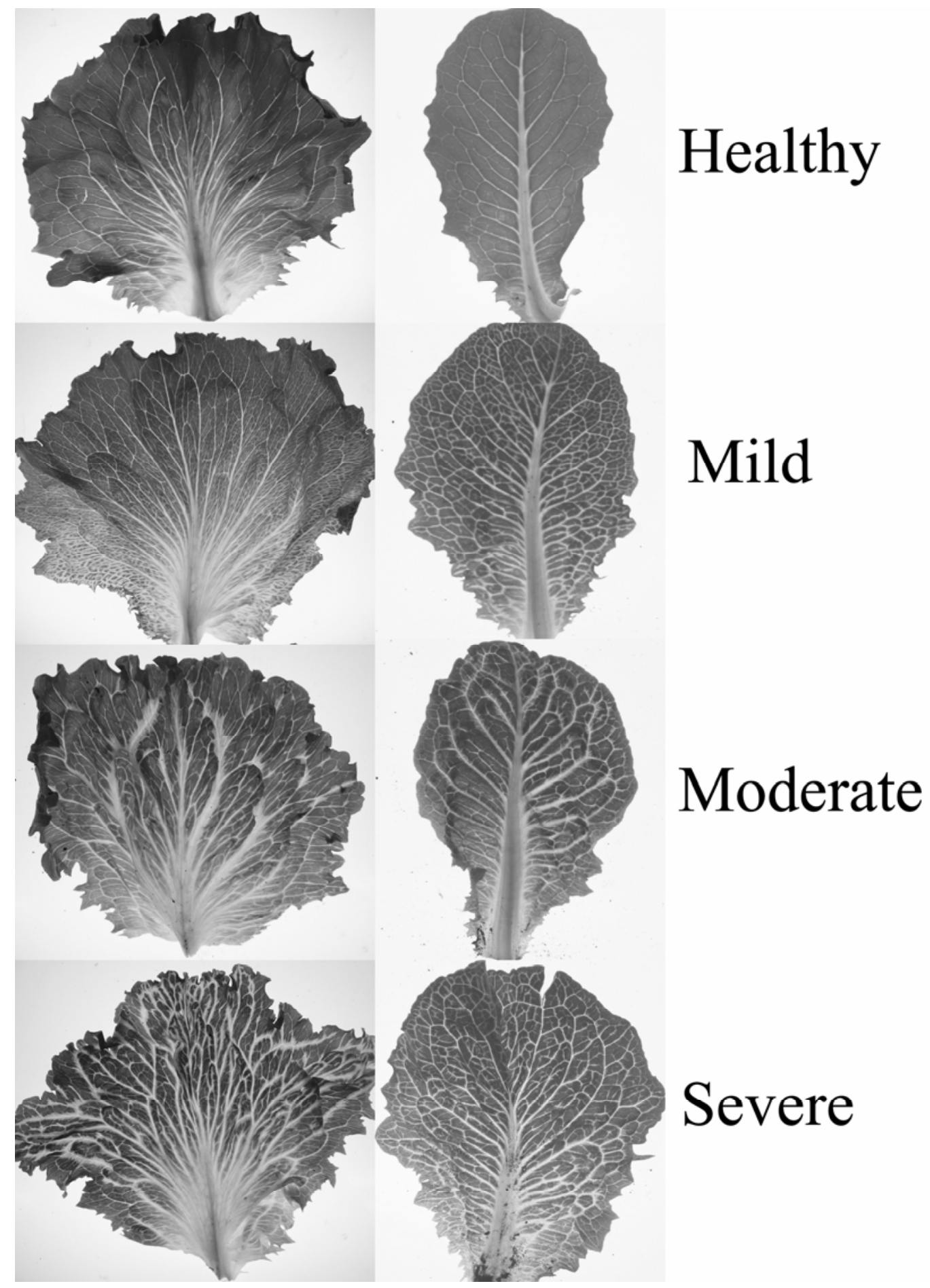

Fig. 1. Big vein symptoms on iceberg (left column) and romaine (right column) lettuce leaves. Healthy = no symptoms. Mild = narrow vein clearing and/or symptoms occurring on less than $50 \%$ of the leaf area. Moderate = both wide and narrow vein clearing, symptoms occurring on more than $51 \%$ of the leaf area, slight shortening and stiffening of the leaf. Severe = wide vein clearing occurring on $100 \%$ of the leaf, pronounced shortening and stiffening of the leaf. 
ratio of field soil to sand, and grown for 3 weeks. A suspension of $O$. brassicae zoospores at greater than 30,000 zoospores per $\mathrm{ml}$ was prepared by collecting big vein symptomatic plants produced at the USDA-ARS research station in Salinas, $\mathrm{CA}$, and macerating the roots in water. The seedlings were inoculated by watering the zoospore suspension into the seedling pots two times with each inoculation, separated by $48 \mathrm{~h}$. Each seedling was subsequently transplanted into an $8-\mathrm{cm}$ pot containing infested field soil. Plants were grown in a greenhouse maintained at $18^{\circ} \mathrm{C}$, and the percentage of symptomatic plants was recorded after 6 to 8 weeks of growth. Tissue was sampled from asymptomatic and symptomatic plants from the third experiment for RNA extraction.

Reverse transcription-polymerase chain reaction (RT-PCR), sequencing, and diversity analysis. Tissue samples were ground in liquid nitrogen, and total RNA was extracted using the Qiagen RNeasy Plant Mini Kit (Qiagen Inc., Valencia, CA) according to the manufacturer's recommendations. RNA extracts were stored at $-80^{\circ} \mathrm{C}$. MLBVV PCR primer pairs (Table 1) were designed from published MLBVV and LBVaV nucleotide sequences. Amplicons were generated by RT-PCR from within each of the four
MLBVV RNAs, from the CP region of LBVaV encoded near the $5^{\prime}$ end of the virus-complementary sense RNA2, as well as from a region near the $3^{\prime}$ end of ORF 5, encoded near the $3^{\prime}$ end of the viruscomplementary sense RNA2 (17). RNA extracts (as well as positive and negative controls, and reagent blanks) were reversetranscribed using MMLV reverse transcriptase (Promega, Inc., Madison, WI) with reaction conditions of $37^{\circ} \mathrm{C}$ for $90 \mathrm{~min}$, and cDNA was amplified with Taq DNA polymerase (Promega). Amplification conditions consisted of 5 min denaturation at $95^{\circ} \mathrm{C}$, followed by 35 cycles of $95^{\circ} \mathrm{C}$ for $1 \mathrm{~min}, 50$ to $56^{\circ} \mathrm{C}$ (depending on primer annealing temperature) for $1 \mathrm{~min}$, and $72^{\circ} \mathrm{C}$ for $1 \mathrm{~min}$, with a final extension at $72^{\circ} \mathrm{C}$ for $10 \mathrm{~min}$. RT-PCR reaction products were separated by electrophoresis on $1 \%$ agarose gels and stained with ethidium bromide to determine the presence or absence of target bands. All samples from which MLBVV or LBVaV RNA did not amplify were re-analyzed using primer pairs made to other regions of the respective viral genomes (Table 1), to rule out the occurrence of false negatives.

Nucleic acid hybridizations were used to confirm positive and negative results from some samples. Clones for probe synthesis and detection of MLBVV were con- structed by cloning the amplification product of primers $829 \mathrm{~F}$ and 1418R (Table 1) on isolate SJ6 obtained from a field near San Juan Bautista, CA. This region encoded a portion of the $\mathrm{CP}$ gene of MLBVV. Clones for use as probes for the detection of $\mathrm{LBVaV}$ were constructed by cloning the amplification product of primers $42 \mathrm{~F}$ and 426R (Table 1) on isolate D3 obtained from a field near Salinas, CA. This region encoded a portion of the $\mathrm{CP}$ gene of LBVaV. Cloning methods were as described below. Probes were synthesized by in vitro transcription using T7 and SP6 promoters and labeling with the DIG RNA Labeling Kit (Roche, Indianapolis, IN). Hybridization and detection involved standard procedures as recommended by Roche.

Nucleic acid sequence diversity. DNA sequencing was performed on one sample from each field. Regions of all four MLBVV RNAs and two regions of LBVaV RNA2 were sequenced for each sample. RT-PCR was performed on these samples using primers with $5^{\prime}$-M13 tails (Table 1). PCR products were purified prior to sequencing with Qiagen kits (QIAquick PCR Purification Kit, or QIAquick Gel Extraction Kit; Qiagen). DNA sequencing was also performed on clones of PCRamplified products for comparison with

Table 1. Primer sets used for amplification of Lettuce big-vein associated virus (LBVaV) and Mirafiori lettuce big-vein virus (MLBVV)

\begin{tabular}{|c|c|c|c|c|c|}
\hline RNA targeted & Primer set ${ }^{\mathbf{a}}$ & $\begin{array}{l}\text { Source } \\
\text { accession no. }\end{array}$ & $\begin{array}{l}\text { Primer used for } \\
\text { virus screening }\end{array}$ & $\begin{array}{l}\text { Primer used for } \\
\text { virus sequencing }\end{array}$ & $\begin{array}{l}\text { Length of ampliconc/ } \\
\text { genome location }\end{array}$ \\
\hline $\begin{array}{l}\text { LBVaV RNA2 } \\
\text { (coat protein) }\end{array}$ & $\begin{array}{l}\text { Forward (CP42 F): CGTCGTG } \\
\text { GAAATCACAGGTAAGAC } \\
\text { Reverse (CP426 R): CGTAGA } \\
\text { GACAGCGATGAATGC }\end{array}$ & BD105437 & Yes & Yes & 385 bp / nt 250-634 \\
\hline $\begin{array}{l}\text { LBVaV RNA2 } \\
\text { (coat protein) }\end{array}$ & $\begin{array}{l}\text { Forward (CP647 F): CAAGGC } \\
\text { AAGCTGAGATGTTGTTCG } \\
\text { Reverse (CP907 R): GAAGGG } \\
\text { TTTGAAAGACRGATGG }\end{array}$ & BD105437 & Yes & & $261 \mathrm{bp} / \mathrm{nt} 855-1115$ \\
\hline $\begin{array}{l}\text { LBVaV RNA2 } \\
\text { (ORF5) }\end{array}$ & $\begin{array}{l}\text { Forward (5068 F): CGGGGAT } \\
\text { CATGAGGAGAAAAACTG } \\
\text { Reverse (6009 R): ACTTGCTT } \\
\text { ATGCGGGCTGGTAG }\end{array}$ & BD105437 & Yes & Yes & 942 bp / nt 5068-6009 \\
\hline MLBVV RNA1 & $\begin{array}{l}\text { Forward ( } 2825 \text { F): CTTGTCTC } \\
\text { TTGATGCCACCTC } \\
\text { Reverse }(3372 \text { R): AACTTGG } \\
\text { GATAGATGGAATGTTTG }\end{array}$ & NC004779 & & Yes & 548 bp / nt 2825-3372 \\
\hline MLBVV RNA2 & $\begin{array}{l}\text { Forward (1100 F): TGGGACT } \\
\text { CCAGTGGTCTTGTATCC } \\
\text { Reverse (1407 R): CGAAGGT } \\
\text { AGAAATAGGAACGATGG }\end{array}$ & NC004781 & & Yes & 308 bp / nt 1100-1407 \\
\hline $\begin{array}{l}\text { MLBVV RNA3 } \\
\text { (coat protein) }\end{array}$ & $\begin{array}{l}\text { Forward (CP829 F): CCWACT } \\
\text { GAGGTTTCATCACGCTG } \\
\text { Reverse (CP1418 R): TATCAG } \\
\text { CTCACATMCTCCCTATCGC }\end{array}$ & AY366417 & Yes & Yes & 590 bp / nt 829-1408 \\
\hline $\begin{array}{l}\text { MLBVV RNA3 } \\
\text { (coat protein) }\end{array}$ & $\begin{array}{l}\text { Forward (CP112 F): AAAGAA } \\
\text { GAGAAGCCTGTYCCTGC } \\
\text { Reverse (CP602 RD): TTGTT } \\
\text { ACCGAGTAACTTGCTGTCG }\end{array}$ & AY366417 & Yes & & $491 \mathrm{bp} / \mathrm{nt} 112-602$ \\
\hline MLBVV RNA4 & $\begin{array}{l}\text { Forward }(271 \mathrm{~F}) \text { : TGAAGGCT } \\
\text { TTCTCATCGGTAGG } \\
\text { Reverse }(840 \mathrm{R}) \text { : CAACCTGG } \\
\text { AACAAGGGCTAAGTTAC }\end{array}$ & NC004780 & & Yes & $570 \mathrm{bp} / \mathrm{nt} 271-840$ \\
\hline
\end{tabular}


sequences generated directly from PCR products. PCR products (one from each of the amplified regions) were cloned using the TOPO TA Cloning Kit (pCR II-TOPO, Invitrogen, Carlsbad, CA) and used to transform Escherichia coli (either TOP10 cells, Invitrogen, or NovaBlue cells, EMD Biosciences, Madison, WI) using standard conditions. Plasmids were prepared with the Qiagen Plasmid Mini Kit prior to sequencing.

Sequencing reactions were performed on purified PCR products or plasmids with the USB Cycle Sequencing Kit (USB, Cleveland, $\mathrm{OH}$ ), using ddNTP termination mixes, and with LI-COR IRDye-labeled M13 primers (LI-COR Inc., Lincoln, NE). Sequence data were generated using the LI-COR Global Edition IR $^{2}$ System and LI-COR eSeq software (v. 3.0). Some samples were sequenced by MCLab (South San Francisco, CA).

Statistical analysis. Chi-square goodness-of-fit was used to test dependence between big vein symptom expression and frequency of infection with MLBVV,
LBVaV, coinfection of MLBVV and LBVaV, and the frequency of big vein symptomatic plants among lettuce genotypes. When analyzing frequencies from field samples, data were pooled within each severity class across all sampling locations. Likewise, data from greenhouse experiments were pooled across inoculations for each genotype. The degree of dependence was calculated according to the method of Steele and Torrie (18). Nucleotide sequence assembly and analysis were conducted using the MacVector 7.0 software (Accelrys Inc., San Diego, CA). Alignments were conducted using ClustalW (19).

\section{RESULTS}

The frequency of MLBVV and LBVaV was dependent on big vein symptom expression from naturally infected plants collected from the field (Table 2). Twentyfive percent (4 of 16) of nonsymptomatic plants were positive for MLBVV, while $100 \%$ of plants with mild, moderate, and severe symptoms were positive for

Table 2. Incidence of Mirafiori lettuce big-vein virus (MLBVV) and Lettuce big-vein associated virus $(\mathrm{LBVaV})$ in field-grown lettuce with no, mild, moderate, and severe symptoms

\begin{tabular}{lccccc}
\hline & \multicolumn{2}{c}{ MLBVV } & & \multicolumn{2}{c}{ LBVaV } \\
\cline { 2 - 3 } \cline { 5 - 6 } Symptom severity & No. positive & No. tested & & No. positive & No. tested \\
\hline No symptoms & 4 & 16 & & 11 & 16 \\
Mild & 15 & 15 & & 15 & 15 \\
Moderate & 15 & 15 & & 15 & 15 \\
Severe & 25 & 25 & & 22 & 25 \\
Total & 59 & 71 & & 63 & 71 \\
$\chi^{2}, 3$ df & & $49.6^{\mathrm{a}}$ & & & $10.2^{\mathrm{a}}$ \\
Degree of dependence & & 0.70 & &
\end{tabular}

Table 3. Dependence of Mirafiori lettuce big-vein virus (MLBVV) and Lettuce big-vein associated virus (LBVaV) incidence in field-grown lettuce

\begin{tabular}{lccc}
\hline & \multicolumn{3}{c}{ LBVaV } \\
\cline { 2 - 4 } MLBVV & Positive & Negative & Total \\
\hline Positive & 56 & 3 & 59 \\
Negative & 7 & 5 & 12 \\
Total & 63 & 8 & 71 \\
$\chi^{2}, 1$ df & & & $129^{\text {a }}$ \\
\hline
\end{tabular}

${ }^{a} P<0.01$.

Table 4. Percent symptomatic plants in big vein-inoculated greenhouse trials of lettuce cultivars Great Lakes 65 (GL65), Margarita, Pavane, and Lactuca virosa accession IVT280

\begin{tabular}{lccc}
\hline Line & No. plants tested & No. symptomatic plants & Percent symptomatic \\
\hline Experiment & & & \\
GL65 & 132 & 100 & 76 \\
Margarita & 127 & 40 & 31 \\
Pavane & 119 & 35 & 29 \\
Total & 378 & 175 & 46 \\
$\chi^{2}, 2$ df & & $24.3^{\mathrm{a}}$ \\
Experiment & & & 81 \\
GL65 & 104 & 0 & 0 \\
IVT280 & 36 & 40 & 38 \\
Pavane & 106 & 131 & 53 \\
Total & 246 & & $34.9^{\mathrm{a}}$ \\
$\chi^{2}, 2$ df & & &
\end{tabular}

MLBVV. Sixty-nine percent (11 of 16) of nonsymptomatic plants were positive for LBVaV. The frequency of $\mathrm{LBVaV}$ in plants with mild and moderate symptoms was $100 \%$, but only $88 \%$ in plants with severe symptoms. In all, the degree of dependence between big vein symptoms and MLBVV (degree of dependence $=0.70$ ) was five times greater than the degree of dependence between big vein symptoms and LBVaV (degree of dependence = $0.14)$.

Coinfection of LBVaV and MLBVV occurred in $79 \%$ of plants, and was a significant association compared with random distribution of each virus (Table 3). All plants with coinfection were symptomatic, but there was no statistically significant relationship between symptom severity and coinfection due to the high frequency of coinfection. Only five samples tested negative for both viruses, all of which were asymptomatic. Seven plants were positive for LBVaV and negative for MLBVV; all of these plants were asymptomatic. Three plants were positive for MLBVV and negative for $\mathrm{LBVaV}$; all three were symptomatic.

Inoculation with $O$. brassicae zoospores from symptomatic plants resulted in significantly different percentages of symptomatic plants among Great Lakes 65, Margarita, and Pavane in experiment 1 (Table 4). In experiment 2, Great Lakes 65, Pavane, and L. virosa accession IVT280 also had significantly different percentages of symptomatic plants (Table 4). Importantly, all plants of $L$. virosa accession IVT280 remained asymptomatic. Detection of MLBVV and LBVaV with RT-PCR confirmed virus infection or coinfection in symptomatic greenhouse-grown lettuce cultivars from experiment 3 , and virus infection patterns paralleled the results from field samples (Table 5). All five symptomatic Great Lakes 65 plants were coinfected with both MLBVV and LBVaV. Among symptomatic Margarita, three plants were positive for MLBVV and three were coinfected with MLBVV and LBVaV. Infection by LBVaV alone could not be detected in any symptomatic plant of any cultivar (Table 5). LBVaV infection and MLBVV/LBVaV coinfection were detected in two asymptomatic plants of Great Lakes 65. Seven plants of Margarita remained asymptomatic. Of these, one plant was positive for both MLBVV and LBVaV, three plants were positive for LBVaV alone, and three plants were negative for both viruses. In all, six of the seven asymptomatic Margarita plants were MLBVV negative. All 14 plants of $L$. virosa IVT280 remained asymptomatic, and no MLBVV or LBVaV was detected in any plants of accession IVT280 (Table 5).

Representative samples of symptomatic lettuce collected from fields located throughout the Salinas Valley (CA) and adjacent lettuce production areas were 
identified that contained MLBVV and LBVaV. All nine California isolates characterized exhibited a high degree of nucleotide sequence conservation with each other (data not shown) as well as with isolates from Europe, Japan, and Yuma, AZ (Tables 6 and 7). Among MLBVV amplicons from California big vein isolates, those from RNA1 exhibited the greatest variability, ranging from 94 to $100 \%$ identity for an amplified fragment 156 nucleotides (nt) in length, with a mean identity of $98.2 \%$ among the nine California isolates. The RNA2 amplicon (227 nt) varied from 95.5 to $100 \%$ identity among these isolates with a mean identity of $97.8 \%$. RNA3 (CP) and RNA4 amplicons were even more highly conserved, ranging from 97.5 to $100 \%$ identity. The mean identities for amplicons of RNA3 (409 nt) and 4 (315 nt) were 99.0 and $98.9 \%$, respectively, when amplicons of the nine California isolates were compared with each other. All four RNAs had at least some isolates with identical amplicon sequences between at least two isolates, although the isolates with complete sequence identity varied among RNAs. Due to the high degree of similarity among California isolates, a representative isolate obtained from a field near Salinas, CA, was used for comparison with international samples. The partial CP (RNA3) amplicon sequence of this isolate (SAL-C6) was compared with correspond- ing sequences of isolates from Arizona, Europe, and Japan (Tables 6 and 7). The California isolates and the lone Arizona isolate YGV1 for which sequence information was available should be classified into MLBVV subgroup B (10) due to higher sequence similarity between these isolates and representative subgroup B isolates MUR1, LS301-O, GER2, Japan, and ITA1, compared to lower sequence similarity with subgroup A representative ALM1 (Table 6).

Analysis of the partial LBVaV CP amplicon (302 nt) and the ORF5 amplicon (310 nt) also revealed a high degree of nucleotide identity among LBVaV isolates from California. The LBVaV CP amplicon varied from 95.8 to $100 \%$ identical at the nucleotide level among the California isolates, with a mean identity of $97.9 \%$ when amplicon sequences were compared among the isolates individually. The LBVaV ORF5 amplicon shared 93.8 to $100 \%$ nucleotide identity with a mean identity of $97.6 \%$ among nine isolates. $\mathrm{LBVaV}$ isolates from California were also highly similar to those from Japan and Europe, sharing 96.8 to $98.7 \%$ identity with similar sequences of those isolates (Tables 6 and 7).

\section{DISCUSSION}

Research on control of big vein disease has been limited by a lack of knowledge regarding the pathogen. Consequently, discovery of MLBVV in big vein symptomatic tissue, and its later report as the causal agent of big vein, was an important breakthrough for big vein research. Determining the occurrence of MLBVV in symptomatic lettuce and understanding the nucleotide sequence diversity of MLBVV isolates are important steps toward furthering big vein research in western U.S. production regions. Our research corroborates previous reports $(9,12)$, showing a strong dependence between big vein symptom expression and MLBVV presence in California-grown lettuce. Additionally, coinfection with both MLBVV and LBVaV was common, and is presumed to result from a shared vector (8). These results are consistent with the findings of Lot et al. (8), that MLBVV is the causal agent of big vein disease.

MLBVV isolates collected from California were highly conserved throughout a sampling area ranging over $3,600 \mathrm{~km}^{2}$, and this conservation was present in amplicons from all four MLBVV RNAs. Nucleotide sequences of MLBVV amplicons vary from 94.2 to $100 \%$ for RNA1, to 97.5 to $100 \%$ for RNAs 3 and 4 . Similarly, amplicons from both the $\mathrm{CP}$ region and a region near the 3' end of LBVaV ORF5 also exhibited a high degree of conservation throughout the sampling area. In recent studies, Navarro et al. (10) compared se-

Table 5. Distribution of Mirafiori lettuce big-vein virus (MLBVV) and Lettuce big-vein associated virus (LBVaV) incidence in symptomatic and asymptomatic lettuce plants of cultivars Great Lakes 65, Margarita, and Lactuca virosa accession IVT280

\begin{tabular}{|c|c|c|c|c|c|c|c|c|c|c|}
\hline \multirow[b]{3}{*}{ Line } & \multicolumn{5}{|c|}{ Symptomatic plants } & \multicolumn{5}{|c|}{ Nonsymptomatic plants } \\
\hline & \multirow[b]{2}{*}{$\begin{array}{c}\text { No. } \\
\text { plants }\end{array}$} & \multicolumn{4}{|c|}{ No. RT-PCR ${ }^{\text {a }}$ positive or negative } & \multirow[b]{2}{*}{$\begin{array}{c}\text { No. } \\
\text { plants }\end{array}$} & \multicolumn{4}{|c|}{ No. RT-PCR positive or negative } \\
\hline & & $\begin{array}{c}\text { Virus } \\
\text { negative }\end{array}$ & $\begin{array}{c}\text { MLBVV } \\
\text { positive }\end{array}$ & $\begin{array}{l}\text { LBVaV } \\
\text { positive }\end{array}$ & $\begin{array}{c}\text { MLBVV } \\
\text { and LBVaV } \\
\text { positive }\end{array}$ & & $\begin{array}{c}\text { Virus } \\
\text { negative }\end{array}$ & $\begin{array}{c}\text { MLBVV } \\
\text { positive }\end{array}$ & $\begin{array}{l}\text { LBVaV } \\
\text { positive }\end{array}$ & $\begin{array}{c}\text { MLBVV } \\
\text { and LBVaV } \\
\text { positive }\end{array}$ \\
\hline Great Lakes 65, uninoc. & 0 & 0 & 0 & 0 & 0 & 7 & 7 & 0 & 0 & 0 \\
\hline Great Lakes 65, inoc. & 5 & 0 & 0 & 0 & 5 & 2 & 0 & 0 & 1 & 1 \\
\hline Margarita, inoc. & 6 & 0 & 3 & 0 & 3 & 7 & 3 & 0 & 3 & 1 \\
\hline L. virosa IVT280, inoc. & 0 & 0 & 0 & 0 & 0 & 14 & 14 & 0 & 0 & 0 \\
\hline
\end{tabular}

${ }^{a}$ Reverse transcription-polymerase chain reaction.

Table 6. Percent nucleotide sequence identity among amplicons of Mirafiori lettuce big-vein virus (MLBVV) and Lettuce big-vein associated virus (LBVaV) coat protein coding regions from isolates representing California (Sal-C6), Arizona (YGV1), Europe, and Asia ${ }^{\mathrm{a}}$

\begin{tabular}{|c|c|c|c|c|c|c|c|}
\hline \multicolumn{8}{|l|}{ Isolate } \\
\hline MLBVV isolates & MUR1 & ALM1 & LS301-O & Japan & GER2 & ITA1 & YGV1 \\
\hline SAL-C6 & 97.5 & 90.9 & 98.5 & 98.5 & 97.3 & 97.8 & 97.8 \\
\hline YGV1 & 98.8 & 91.9 & 99.3 & 99.3 & 99.0 & 97.1 & \\
\hline ITA1 & 95.8 & 91.2 & 96.8 & 96.8 & 96.1 & & \\
\hline GER2 & 96.3 & 91.0 & 98.8 & 98.8 & & & \\
\hline Japan & 97.6 & 91.7 & 100.0 & & & & \\
\hline LS301-O & 97.6 & 91.7 & & & & & \\
\hline ALM1 & 90.2 & & & & & & \\
\hline $\mathrm{LBVaV}$ isolates & Japan & GAL1 & ALM5 & GRA1 & UK2 & MUR2 & \\
\hline SAL-C6 & 96.8 & 97.7 & 98.1 & 98.7 & 98.1 & 98.1 & \\
\hline MUR2 & 96.8 & 99.7 & 98.7 & 98.7 & 98.1 & & \\
\hline UK2 & 96.1 & 97.7 & 98.1 & 98.7 & & & \\
\hline GRA1 & 96.8 & 98.4 & 99.4 & & & & \\
\hline ALM5 & 96.8 & 98.4 & & & & & \\
\hline GAL1 & 96.4 & & & & & & \\
\hline
\end{tabular}

${ }^{a}$ Isolate origins and accession numbers are listed in Table 7. 
quence variability within the $\mathrm{CP}$ coding regions of MLBVV and $\mathrm{LBVaV}$ isolates from throughout Europe. A single $\mathrm{LBVaV}$ isolate from California was also included. Comparative analysis identified two subgroups of MLBVV based on CP variation, however, both LBVaV and MLBVV exhibited a high degree of nucleotide sequence conservation among isolates examined (10). MLBVV isolates compared in this study were most similar to isolates of subgroup A (97 to $99 \%$ identity), but less closely related to subgroup B isolate ALM1 (10). The sequence identity of all isolates irrespective of subgroup designation was greater than $90 \%$. California and Arizona isolates shared 98 to $100 \%$ sequence identity with one another in the region of the MLBVV CP gene. Navarro et al. (10) found similar levels of conservation among subgroup B isolates, and only slightly more variation among subgroup A isolates (96 to $99.5 \%$ conservation). Both the Navarro (10) study, which focused on European isolates of LBVaV and MLBVV, and the study described herein, which focused on U.S. isolates, examined the CP coding region of these viruses. Although this study examined only a subset of the region analyzed by Navarro et al. (10), the results were similar. Furthermore, analysis of additional regions of the viral genomes as described herein concurred, indicating a high level of sequence conservation among both LBVaV and MLBVV isolates from not only the western United States, but also with those from other parts of the world (10). Limited diversity was found in lettuce isolates of MLBVV and LBVaV. Additional symptomatic hosts of big vein, including Chicorium endivia L. (endive), Sonchus oleraceus L. (sow thistle), and several other Lactuca spp. (3), may exhibit greater nucleotide sequence variability among virus isolates than is found in lettuce.

Table 7. Origin, accession number, and genomic region sequenced for Mirafiori lettuce big-vein virus (MLBVV) and Lettuce big-vein associated virus (LBVaV) isolates used in comparative studies

\begin{tabular}{lllll}
\hline Isolate & Origin & Region amplified & MLBVV & LBVaV \\
\hline LS301-O & Netherlands & RNA 1 & NC004779 & \\
LS301-O & Netherlands & RNA 2 & NC004781 & \\
LS301-O & Netherlands & RNA 3 & NC004782 & \\
LS301-O & Netherlands & RNA 4 & NC004780 & \\
ITA1 & Italy & CP & AY581699 & \\
GER2 & Germany & CP & AY581697 & \\
ALM1 & Spain & CP & AY366417 & \\
MUR1 & Spain & CP & AY366415 & \\
YGV1 & Yuma, AZ, USA & Partial CP & DQ191062 & \\
Unnamed & Japan & CP & AF532872 & AB050272 \\
MUR2 & Spain & CP & & AY581691 \\
UK2 & England & CP & & AY581690 \\
GRA1 & Spain & CP & & AY581689 \\
ALM5 & Spain & CP & & AY581686 \\
GAL1 & Spain & CP & & BD105437 \\
Unnamed & Japan & RNA 2 & DQ182562 & \\
SAL-C6 & Salinas, CA, USA & Partial RNA1 & DQ182563 & \\
SAL-C6 & Salinas, CA, USA & Partial RNA2 & DQ182564 & \\
SAL-C6 & Salinas, CA, USA & Partial CP & DQ182565 & \\
SAL-C6 & Salinas, CA, USA & Partial RNA4 & & DQ182566 \\
SAL-C6 & Salinas, CA, USA & Partial CP & & \\
\hline
\end{tabular}

symptomless plants had no detectable virus by RT-PCR is important. Big vein resistance breeding efforts using IVT280 are being pursued. Hayes (5) reported that backcross 1 hybrid breeding lines demonstrated variation for the frequency of symptomatic plants, a type of resistance similar to that observed in cultivated lettuce. No L. virosa-L. sativa hybrid breeding lines with immunity ( 0 symptomatic plants) were recovered (5). It is likely that symptomless infection confounded selection efforts for immune genotypes, and may have contributed to the lack of resistance in backcross $L$. virosa- $L$. sativa populations. Consequently, the ability to detect MLBVV accumulation in symptomless plants as done in this paper will greatly improve breeding efforts for big vein resistance derived from $L$. virosa.

\section{LITERATURE CITED}

1. Anonymous. 2004. Statistics of Vegetables and Melons. U.S. Dep. Agric.-National Agriculture Statistics Service (NASS). Online publication.

2. Bos, L., and Huijberts, N. 1990. Screening for resistance to big vein disease of lettuce. Crop Prot. 9:446-452.

3. Campbell, R. N. 1965. Weeds as reservoir hosts of the lettuce big-vein virus. Can. J. Bot. 43:1141-1149.

4. Campbell, R. N., and Grogan, R. G. 1963. Big vein virus of lettuce and its transmission by $\mathrm{Ol}$ pidium brassicae. Phytopathology 53:252-259.

5. Hayes, R. J., Ryder, E., and Robinson, B. 2004. Introgression of Big Vein Tolerance from Lactuca virosa L. into Cultivated Lettuce (Lactuca sativa L.). HortScience 39:881.

6. Huijberts, N. D., Blystad, R., and Bos, L. 1990. Lettuce big vein virus: Mechanical transmission and relationships to tobacco stunt virus. Ann. Appl. Biol. 116:463-475.

7. Jagger, I. C., and Chandler, N. 1934. Big vein, a disease of lettuce. Phytopathology 24:12531256

8. Lot, H., Campbell, R. N., Souche, S., Milne, R. G., and Roggero, P. 2002. Transmission by Olpidium brassicae of Mirafiori lettuce virus and Lettuce big-vein virus, and their roles in lettuce big-vein etiology. Phytopathology 92:288-293.

9. Navarro, J. A., Botella, F., Maruhenda, A., Sastre, P., Sanchez-Pina, M. A., and Pallas, V. 2004. Comparative infection progress analysis of Lettuce big-vein virus and Mirafiori lettuce virus in lettuce crops by developed molecular diagnosis techniques. Phytopathology 94:470477.

10. Navarro, J. A., Torok, V. A., Vetten, H. J., and Pallas, V. 2005. Genetic variability in the coat protein genes of lettuce big-vein associated virus and Mirafiori lettuce big-vein virus. Arch. Virol. 150:681-694.

11. Roggero, P., Ciuffo, M., Varia, A. M., Accotto, G. P., Masenga, V., and Milne, R. G. 2003. An ophiovirus isolated from lettuce with big vein symptoms. Arch. Virol. 145:2629-2642.

12. Roggero, P., Lot, H., Souche, S., Lenzi, R., and Milne, R. G. 2003. Occurrence of Mirafiori lettuce virus and Lettuce big vein virus in relation to development of big vein symptoms in lettuce crops. Eur. J. Plant Pathol. 109:261267.

13. Rosales, I. M., Sepulveda, P., and Bruna, A. 2004. First report of Lettuce big-vein virus and Mirafiori lettuce virus in Chile. Plant Dis. 88:1286.

14. Ryder, E. J. 1979. Effects of big vein resistance and temperature on disease incidence and percentage of plants harvested of 
crisphead lettuce. J. Am. Soc. Hortic. Sci. 104:665-668.

15. Ryder, E. J., and Robinson, B. J. 1995. Big-vein resistance in lettuce: Identifying, selecting, and testing resistance cultivars and breeding lines. J. Am. Soc. Hortic. Sci. 120:741-746.

16. Sasaya, T., Ishikawa, K., and Koganezawa, $H$. 2002. The nucleotide sequence of RNA1 of Lettuce big-vein virus, genus Varicosavirus reveals its relation to nonsegmented negativestrand RNA viruses. Virology 297:289-297.

17. Sasaya, T., Kusaba, S., Ishikawa, K., and Koganezawa, H. 2004. Nucleotide sequence of RNA 2 of Lettuce big-vein virus and evidence for a possible transcription termination/ initiation strategy similar to that of rhabdovi- ruses. J. Gen. Virol. 85:2709-2717.

18. Steele, R. G. D., and Torrie, J. H. 1980. Principles and Procedures of Statistics: A Biometrical Approach. McGraw Hill, New York.

19. Thompson, J. D., Higgins D. G., and Gibson, T. J. 1994. CLUSTALW: Improving the sensitivity of progressive multiple sequence alignment through sequence weighting, position-specific gap penalties and weight matrix choice. Nucleic Acids Res. 22:46734680 .

20. van der Wilk, F., Dullemans, A. M., Verbeek, M., and van den Heuvel, J. F. J. M. 2002. Nucleotide sequence and genomic organization of an ophiovirus associated with lettuce big-vein disease. J. Gen. Virol. 83:2869-2877.
21. Vetten, H. J., Lesemann, D. E., and Dalchow, J. 1987. Electron microscopical and seriological detection of virus-like particles associated with lettuce big vein disease. J. Phytopathol. 120:53-59.

22. Westerlund, F. V., Campbell, R. N., and Grogan, R. G. 1978. Effect of temperature on transmission, translocation, and persistence of the lettuce big-vein agent and big-vein symptom expression. Phytopathology 68:921-926.

23. Westerlund, F. V., Campbell, R. N., Grogan, R. G., and Duniway, J. M. 1978. Soil factors affecting the reproduction and survival of $\mathrm{Ol}$ pidium brassicae and its transmission of big vein agent to lettuce. Phytopathology 68:927 935 . 